\title{
Thinking inside the Box: Tissue Culture for Plant Propagation in a Key Ecological Species, Andropogon gerardii
}

\author{
Ava M. Hoffman*, Melinda D. Smith \\ Department of Biology/Graduate Degree Program in Ecology, Colorado State University, Fort Collins, USA \\ Email: *Ava.Hoffman@colostate.edu
}

How to cite this paper: Hoffman, A.M. and Smith, M.D. (2018) Thinking inside the Box: Tissue Culture for Plant Propagation in a Key Ecological Species, Andropogon gerardii. American Journal of Plant Sciences, 9, 1987-2003.

https://doi.org/10.4236/ajps.2018.910144

Received: June 28, 2018

Accepted: September 2, 2018

Published: September 5, 2018

Copyright ( 92018 by authors and Scientific Research Publishing Inc. This work is licensed under the Creative Commons Attribution International License (CC BY 4.0).

http://creativecommons.org/licenses/by/4.0/

\begin{abstract}
Intraspecific diversity has widespread effects on ecological communities and ecosystems. To elucidate the mechanisms underlying these effects, manipulative studies require a rigorous and efficient empirical approach. Yet, replicating sufficient numbers of genetically identical individuals remains a challenge. As a result, we are limited in our understanding of the mechanisms underlying the ecological effects of intraspecific diversity. In contrast, large sample sizes are routinely produced in horticultural research using micropropagation, or tissue culture. In order to determine the potential usefulness of micropropagation technique for ecological studies, we investigated the efficiency and efficacy of micropropagation on the ecologically important non-model C4 grass species, Andropogon gerardii. Our preliminary results demonstrate that micropropagation is a rapid and effective technique for producing large numbers of genetically identical clones at up to 100 times the rate of traditional propagation. Key intraspecific differences among clones of $A$. gerardii were also retained through the micropropagation process. Given that traditional techniques used to test the effects of intraspecific diversity manipulations are time-limiting (greenhouse propagation) or can be biologically misrepresentative (seeds) for some species, we suggest that micropropagation might be a powerful tool for advancing ecological genetics studies in many plant systems.
\end{abstract}

\section{Keywords}

Intraspecific Diversity, Micropropagation, Perennial Grass, Ecology

\section{Introduction}

Intraspecific diversity of plants can have strong effects on ecosystems, from in- 
fluencing community species richness and insect diversity to enhancing ecosystem function [1] [2] [3] [4]. In order to test the effects of intraspecific diversity empirically, ecologists typically assemble artificial communities of genotypes or ecotypes [4] [5] [6] [7]. Although a number of investigators have successfully performed these kinds of experiments (e.g., [8]), generating large numbers of individuals from specific genotypes remains a challenge in many species. These large numbers of individuals are necessary to draw conclusions across a range of spatial scales and different resolutions of genetic variation (within vs. among populations) with more confidence, especially when variation is high and reproducibility is a recognized need in ecology [9] [10] [11]. Understanding interdependent variables, such as the interactions between climate change, drought, and disease, will require even larger sample sizes [12] [13] [14] [15]. Thus, it is unsurprising that many integrative intraspecific diversity studies use quickly reproducing model plants instead of ecologically important non-model species. This disparity presents a substantial knowledge gap for relevant species and limits our understanding of intraspecific diversity in natural ecosystems.

Several approaches are available to test the ecological effects of intraspecific diversity in manipulative studies (Figure 1). These typically include genotype collection and replanting [16] [17], planting different seed accessions [4] [18] [19], and propagating clonal plants in a greenhouse environment [1] [20] [21]. Nearly all intraspecific diversity studies lack micropropagation (also known as tissue culture "in vitro" propagation), a technique widely used in crop science and horticulture to generate large numbers of genetically identical individuals for commercial planting or research [22]. For non-model species, tissue culture techniques can make commercialization possible (e.g., indouglas-fir [23]). Yet, use of micropropagated plants is rarely suggested for ecological research [24].

Investigating intraspecific diversity in ecology is especially urgent in vulnerable ecosystems faced with the looming threats brought on by climate change. For example, the tallgrass prairies of the Midwestern United States will be particularly susceptible to future droughts [25]. In this ecosystem, the $\mathrm{C}_{4}$ grass Andropogon gerardii is largely responsible for ecological function, comprising up to $80 \%$ of production [26]. This species recruits primarily through tillering from underground rhizomes and rarely from seed [27] [28] [29] [30] [31]. Andropogon gerardii is also self-incompatible (produces genetically recombined genotypes) and has common sterile polyploid cytotypes [32] [33] [34]. These traits suggest that planting seeds of different $A$. gerardii genotypes would not be biologically representative. Genotypes are also difficult to distinguish without quantifying genetic markers, so field collection is also unreliable. Thus, any intraspecific studies performed with this and other similar species are likely to need forms of plant propagation. Greenhouse propagation can take many years [20], however micropropagation techniques could substantially reduce this timeframe.

Here, we provide evidence for the validity of the micropropagation technique within ecology by testing these methods on this ecologically important, clonally 


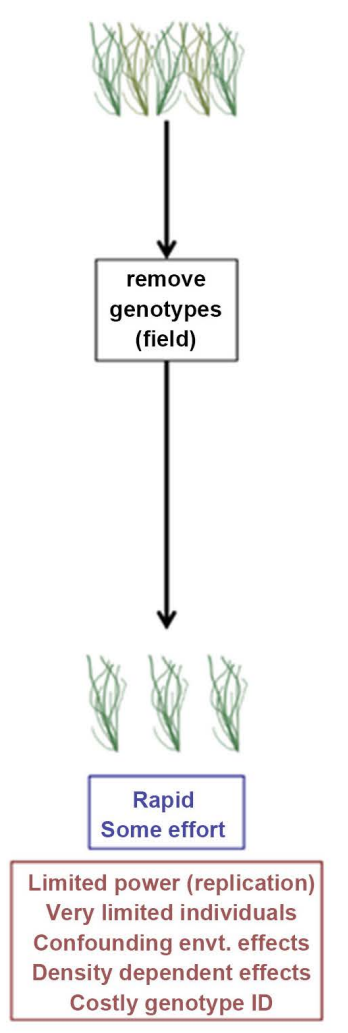

(a)

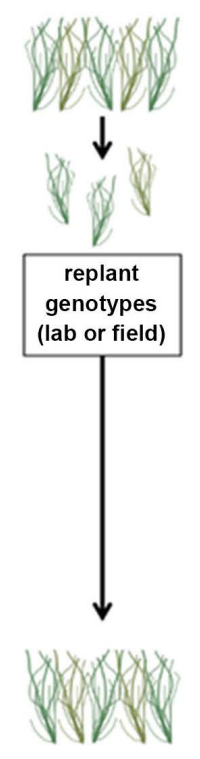

Rapid Some effort

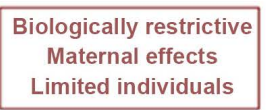

(b)
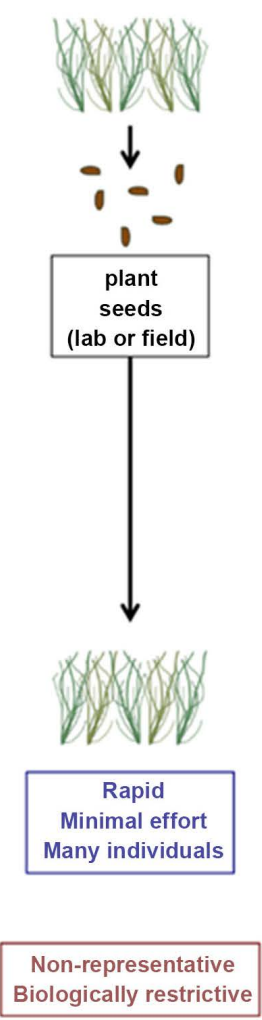

(c)

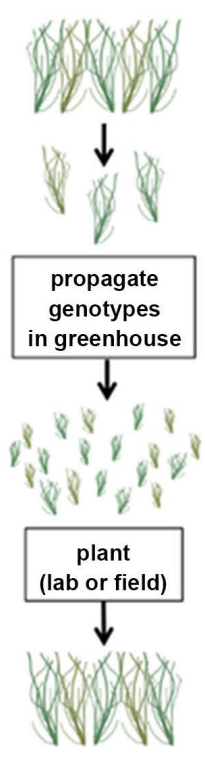

No maternal effects Higher power (replication)
Many individuals

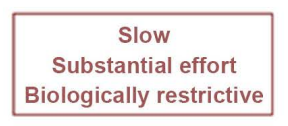

(d)

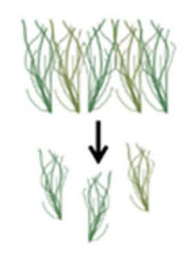

micropropagation of genotypes
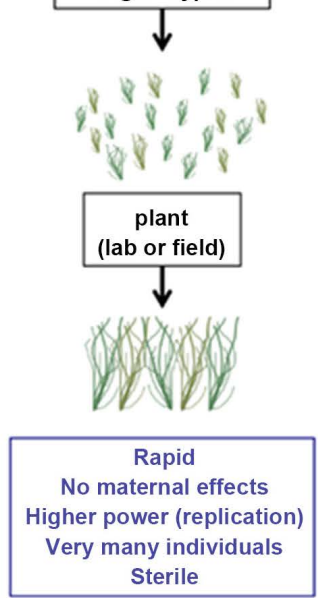

Exploration of new technique Possible cost limitations

(e)

Figure 1. Experimental approaches utilized in studies manipulating plant genetic diversity typically include (a) field genotype manipulation by removal, (b) harvesting and replanting genotypes, (c) planting seeds of different genotype, (d) propagating and replanting genotypes in a greenhouse environment, or (e) propagating and replanting genotypes using tissue culture. Positive (blue) and negative (red) attributes of each approach are boxed.

reproducing species. We developed a tissue culture protocol building upon the only previously known protocol developed for $A$. gerardii [35]. Our goal was to test the efficacy and efficiency of this technique for ecological non-model species using several genotypes of $A$. gerardii. For micropropagation to be effective, a large number of individuals representing different genotypes need to be generated in a short period of time. We expected this technique to be effective for $A$. gerardii due to the success of micropropagation for many species in horticulture and A. gerardiis clonal growth habit. Successful development of this protocol for an ecologically important non-model species will help encourage more efficient study of the ecological effects of intraspecific diversity on communities and ecosystems.

\section{Materials and Methods}

\subsection{Study Species}

Andropogon gerardii (big bluestem) is found throughout most of eastern North America and is the dominant species in the tallgrass prairie ecosystems of the central and eastern Great Plains [36]. Depending on fire and grazing manage- 
ment, $A$. gerardii contributes a large proportion to primary producer biomass [26] and controls plant community structure [37], and is thus of great ecological interest for prairie ecosystems. Due to its ecological and commercial importance [38] [39], a number of studies have already investigated genetic diversity in this species [7] [40]-[47]. We selected three hexaploid genotypes from one population [46] to propagate in tissue culture for later use in an ecological study. The focal genotypes of $A$. gerardii have been shown to respond differentially to drier conditions and have previously been genotyped using amplified fragment length polymorphisms (AFLPs) [47]. Drought studies focused on intraspecific diversity in $A$. gerardii will be of increasing importance due to changing climate, including increased risk of climate extremes and altered timing of rainfall events in the Great Plains [25] [48] [49].

\subsection{Tissue Culture}

Micropropagation was started from greenhouse potted genotypes of $A$. gerardii selected by M. Avolio from a single population at the Konza Prairie Biological Station in Manhattan, KS [41]. Plants were excised below actively growing meristem using tools dipped in $70 \%$ isopropyl alcohol. Rhizome was included wherever possible. Excised plants were then sterilized using a $0.5 \%$ bleach solution with gentle shaking before transporting to a laminar flow hood with HEPA filter. Meristematic regions were identified as rhizomatous nodes and gently scrubbed with $3 \%$ hydrogen peroxide to remove any residual soil. Nodes were excised and placed on a rotary shaker in 3\% hydrogen peroxide for at least 2 hours. Nodes were then separated into separate tubes and shaken for 10 minutes in sterile water with $10 \%$ bleach and $50 \mu \mathrm{L}$ per L of Tween-20 solution. Meristematic nodes were then placed on $10 \mathrm{~mL}$ solid " $3 \mathrm{BX}$ " MS-based growth media [50] for shoot initiation (Table 1). Due to fungal or bacterial presence, contaminated tubes were frequently swapped for fresh media during an 8 week period to establish sterile cultures.

Magenta-style tissue culture boxes containing $60 \mathrm{~mL}$ solid "2BX" MS-based growth media (Table 1) were prepared ahead of time and autoclaved for $30 \mathrm{mi}$ nutes, after which boxes were sprayed with $70 \%$ ethanol and allowed to solidify overnight. Boxes were monitored for several days before use to ensure no contamination. Media was prepared in the Horticulture department facilities at Colorado State University. Genotypes 2 (G2), 5 (G5), and 11 (G11) [46] were the focus of this study. Names of these genotypes correspond to ranked abundance in the field (i.e., G2 is the second most abundant genotype). These genotypes are abundant in the Konza Prairie Rainfall Manipulation Study with implications for ecosystem function under changing precipitation regimes [47]. Previous study has shown that G2 and G11 is drought tolerating while G5 is susceptible to water limitation [46] [47]. Five, eight, and nine plants of G2, G5, and G11, respectively, were transferred on 4 April 2014 to media boxes with flame-sterilized tools in a laminar flow hood with HEPA filter at the U.S. Department of Agriculture 
Table 1. Culture media recipes used in $A$. gerardii micropropagation. MS salts: Murishage \& Skoog basal salt mixture [50]. Media was prepared in $5 \mathrm{~L}$ Erlenmeyer flasks with a stirring bar. Once the water was hot but not boiling, salts and micronutrients were added and $\mathrm{pH}$ was adjusted to 5.7 using sodium hydroxide solution. The mixture was then brought to a light boil before adding sucrose and gellan gum. Media was stirred rapidly and heated until all sucrose and gellan gum was dissolved, approximately 5 - 10 minutes. All reagents were purchased from Phytotechnology Laboratories, Overland Park, KS.

\begin{tabular}{|c|c|}
\hline Media recipe: $1 \mathrm{~L}$ reverse-osmosis water & Volume \\
\hline \multicolumn{2}{|l|}{ 3BX: Shoot initiation } \\
\hline Sucrose & $30 \mathrm{~g} / \mathrm{L}$ \\
\hline Myo-inositol & $100 \mathrm{mg} / \mathrm{L}$ \\
\hline MS salts & $4.3 \mathrm{~g} / \mathrm{L}$ \\
\hline Gelritegellan gum & $2 \mathrm{~g} / \mathrm{L}$ \\
\hline Glycine & $2 \mathrm{mg} / \mathrm{L}$ \\
\hline Nicotinic acid & $0.5 \mathrm{mg} / \mathrm{L}$ \\
\hline Pyridoxine & $0.5 \mathrm{mg} / \mathrm{L}$ \\
\hline Thiamine $\mathrm{HCl}$ & $0.4 \mathrm{mg} / \mathrm{L}$ \\
\hline $\mathrm{N}^{6}$-Benzyladenine & $3 \mathrm{mg} / \mathrm{L}$ \\
\hline \multicolumn{2}{|l|}{ 2BX: Shoot initiation } \\
\hline Sucrose & $30 \mathrm{~g} / \mathrm{L}$ \\
\hline Myo-inositol & $100 \mathrm{mg} / \mathrm{L}$ \\
\hline MS salts & $3.4 \mathrm{~g} / \mathrm{L}$ \\
\hline Gelritegellan gum & $2 \mathrm{~g} / \mathrm{L}$ \\
\hline Glycine & $2 \mathrm{mg} / \mathrm{L}$ \\
\hline Nicotinic acid & $0.5 \mathrm{mg} / \mathrm{L}$ \\
\hline Pyridoxine & $0.5 \mathrm{mg} / \mathrm{L}$ \\
\hline Thiamine $\mathrm{HCl}$ & $0.4 \mathrm{mg} / \mathrm{L}$ \\
\hline $\mathrm{N}^{6}$-Benzyladenine & $2 \mathrm{mg} / \mathrm{L}$ \\
\hline \multicolumn{2}{|l|}{ 0BX: Root initiation } \\
\hline Sucrose & $30 \mathrm{~g} / \mathrm{L}$ \\
\hline Myo-inositol & $100 \mathrm{mg} / \mathrm{L}$ \\
\hline MS salts & $4.3 \mathrm{~g} / \mathrm{L}$ \\
\hline Gelritegellan gum & $2 \mathrm{~g} / \mathrm{L}$ \\
\hline Glycine & $2 \mathrm{mg} / \mathrm{L}$ \\
\hline Nicotinic acid & $0.5 \mathrm{mg} / \mathrm{L}$ \\
\hline Pyridoxine & $0.5 \mathrm{mg} / \mathrm{L}$ \\
\hline Thiamine $\mathrm{HCl}$ & $0.4 \mathrm{mg} / \mathrm{L}$ \\
\hline
\end{tabular}

National Center for Genomic Resources Preservation (USDA-NCGRP), Fort Collins, CO. Boxes were placed in a walk-in growth chamber at the USDANCGRP and provided a 16 hour photoperiod at $25^{\circ} \mathrm{C}$ and $20 \%-30 \%$ humidity.

Plants were allowed to propagate for 24 days, during which clumps of indi- 
viduals were produced (Figure 2(a)). Individuals were then transferred with forceps to boxes containing "0BX" rooting media (Table 1; Figure 2(b)). Plants grew roots for 50 days before being transferred to misting benches at Plant Growth Facilities, Colorado State University. Transfer to the greenhouse involved rinsing residual media from plant roots with water, weighing individual fresh plants, and placing individuals into moist fritted clay media (Porous Ceramic "Greens Grade", Profile Products LLC, Buffalo Grove, IL). Height and tiller count measurements were collected on these individuals on day 6 (early) following transfer. Plants were allowed to adjust in misters for 42 days before being placed in $2.65 \mathrm{~L}$ cone-tainer style tree pots for further study (Stuewe \& Sons, Tangent, OR).

\subsection{Statistical Analyses}

We tested whether genotypes differed in trait values to provide evidence for phenotypic diversity emerging from genetic diversity. We compared plant mass, height, and tiller count, genotypes using robust regression linear models (using the $\mathrm{M}$ estimator), a method that accommodates unequal variance. Following pairwise comparisons, we adjusted p-values using Tukey adjustments and corrections for false discovery rates. Differences in variances among genotypes were tested using two-sided $\mathrm{F}$ tests on each pairwise comparison with Bonferroni adjustments. All statistical analyses were performed using R (version 3.5.0, [51]) with open-source code

(https://github.com/avahoffman/tissue-culture-andropogon).

\section{Results}

All three $A$. gerardii genotypes experienced very high rates of micropropagation. Five, eight, and nine plants of G2, G5, and G11, respectively, were transferred on 4 April 2014. These parent plants yielded 105, 110, and 121 plants of each genotype, respectively, 24 days later. For G2, we found that $38 \%$ had already developed roots after 17 days in rooting media. For G5, 76\% had developed roots and for G11, we found that $45 \%$ had developed roots in rooting media. Plants with developed roots were transferred to the greenhouse on 17 June 2014, totaling 108 , 118, and 135 plants of G2, G5, and G11, respectively (Table 2 ). The propagation rate in this study was approximately $6.1 \times, 4 \times$, and $3.9 \times$ new plants for every parent plant per week. Despite some mortality during the rooting stage (28\%, $4 \%$, and $27 \%$ mortality for G2, G5, and G11, respectively), plants continued propagating in hormone-free rooting media. This resulted in a higher number of plants transferred to the greenhouse than initially started on rooting media. After tissue culture plants were transferred to the greenhouse, A. gerardii experienced surprisingly high rates of survival. On July 29, plants were transferred to pots for future study. A total of 108, 117, and 134 plants were transferred to pots from G2, G5, and G11, resulting in 100\%, 99.2\%, and $99.3 \%$ survival during the greenhouse adjustment phase in each genotype, respectively. 


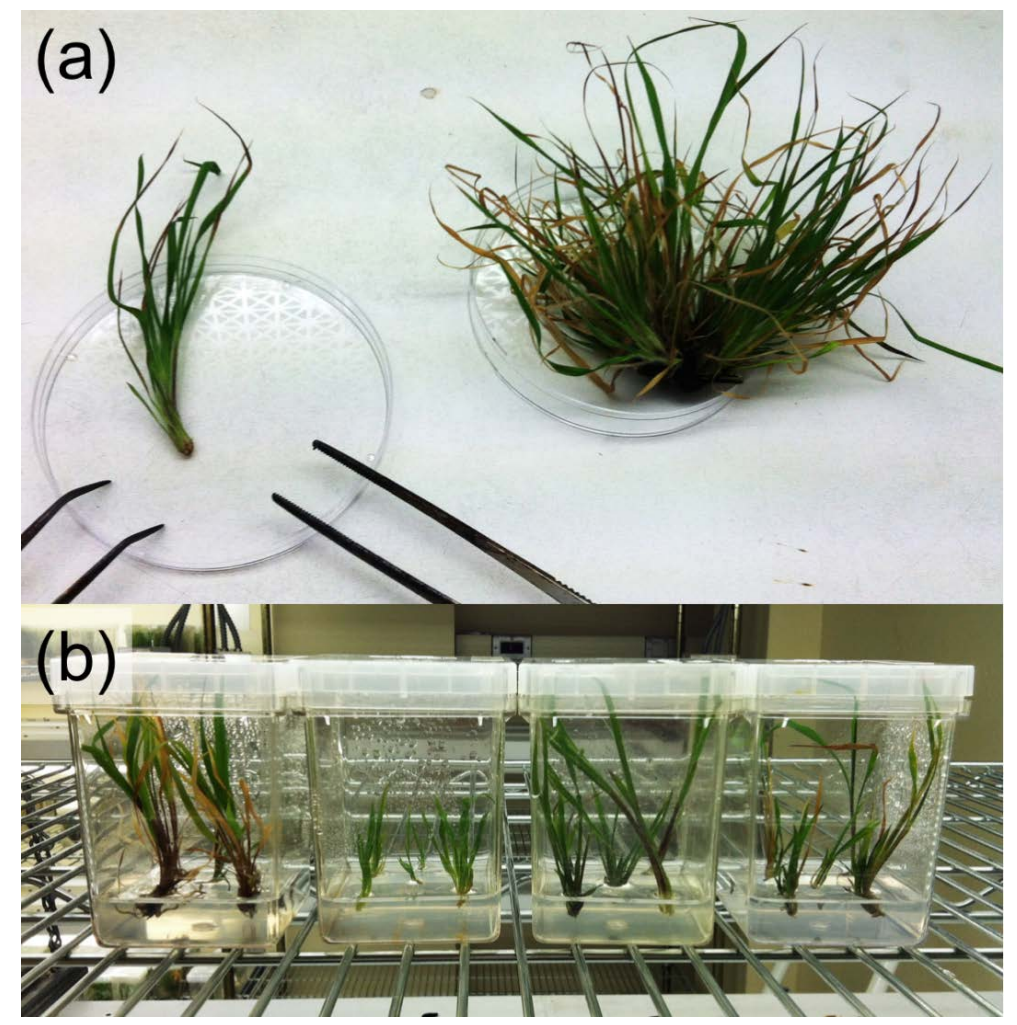

Figure 2. Micropropagation was successful in Andropogon gerardii. (a) Clumps of propagated plants (right) were separated into individuals (left). Individuals were then placed in rooting media (b). Boxes are arranged from left to right by genotype: G5, G1 (not used in this study), G2, and G11.

Table 2. Propagation summary for $A$. gerardii genotypes. Propagation rate refers to the number of new plants per each starting plant. "Day 17" indicates seventeen days following transfer into 0BX rooting media. "Plants transferred to greenhouse" indicates the number of plants that survived rooting and were transferred to non-sterile conditions.

\begin{tabular}{cccc}
\hline Genotype & G2 & G5 & G11 \\
\hline Starting plants & 5 & 8 & 9 \\
Propagation rate & $6.1 /$ week & $4 /$ week & $3.9 /$ week \\
Day 17: rooting stage mortality & $28 \%$ & $4 \%$ & $27 \%$ \\
Day 17: plants with roots & $38 \%$ & $76 \%$ & $45 \%$ \\
Plants transferred to greenhouse & 108 & 118 & 135 \\
\hline
\end{tabular}

Differences between genotypes were examined in the greenhouse at the start of the acclimation stage, where plants were located under misters between tissue culture and placement in the ecological study. We found that genotypes varied significantly in mean starting mass, height, and tiller count (Figure 3 ). Genotype 2 had significantly greater mass than G5 $(\mathrm{z}=-2.770, \mathrm{p}<0.001)$ and G5 had significantly greater mass than G11 $(z=-3.665, p<0.001)$. Genotype 5 was the tallest genotype (compared to $\mathrm{G} 2, \mathrm{z}=4.596, \mathrm{p}<0.001$ ) and $\mathrm{G} 11$ was the shortest (compared to $\mathrm{G} 2, \mathrm{z}=-2.282, \mathrm{p}=0.023$ ). Genotype 11 has significantly more 

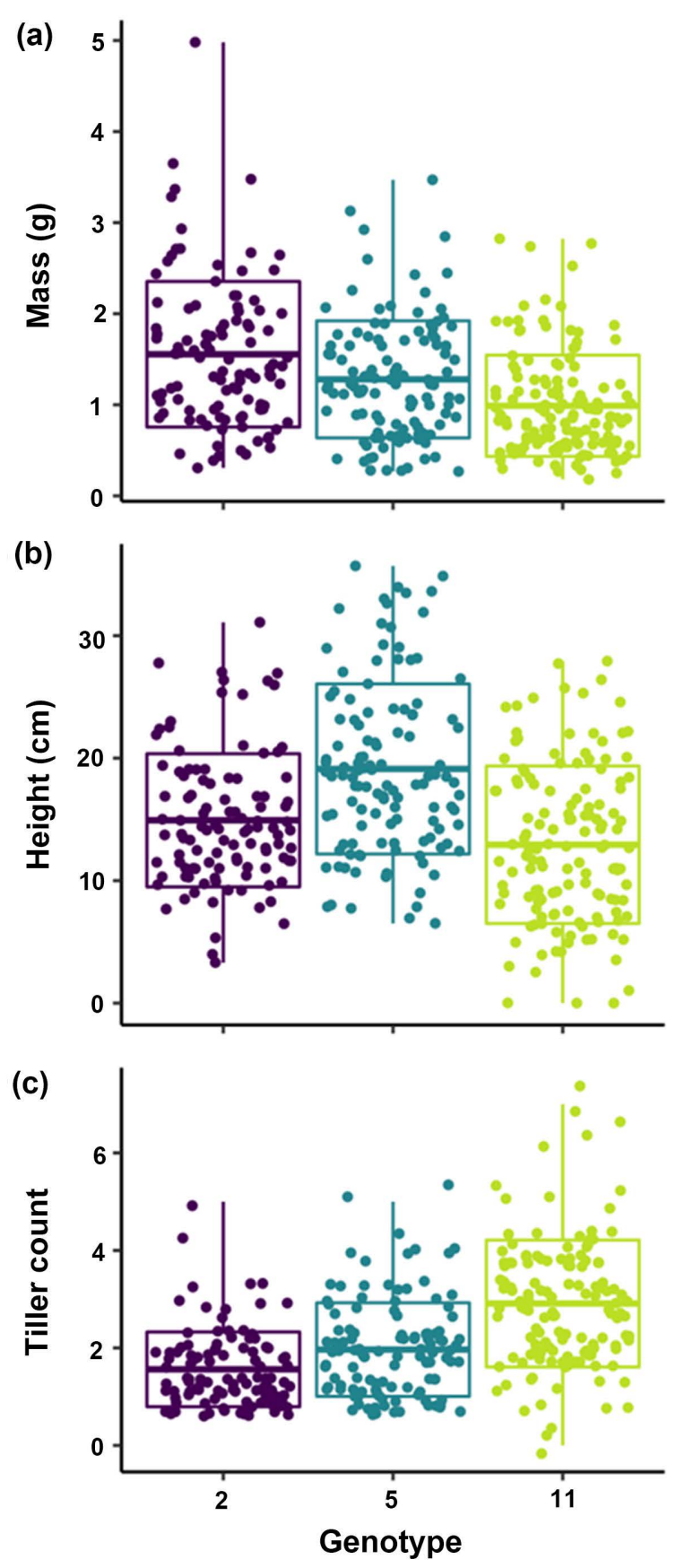

Figure 3. Traits of three genotypes of propagated plants including (a) mass, (b) height, and (c) tiller count were variable. Boxplots indicate maximum, minimum, and the mean $+/-$ one standard deviation. Note that weight (a) is fresh weight, not dried weight.

tillers than G5 $(\mathrm{z}=8.162, \mathrm{p}<0.001)$ whereas $\mathrm{G} 2$ had the fewest tillers $(\mathrm{z}=2.763$, $\mathrm{p}=0.005)$. Genotypes also showed differences in trait variation. Genotype 2 showed the more variation in mass compared to G11 $(p<0.001)$ but variation between G2 and G5 (p = 0.065) and G5 and G11 ( $p=0.310)$ were not significant. Variation in height was different between G2 and G5 ( $p=0.032)$ but not differ- 
ent between G2 and G11 ( $p=0.215$ ) or between G5 and G11 ( $p=1.000)$. Lastly, G11 had the most variation in number of tillers (compared to G2, p 0.001 and compared to G5, $\mathrm{p}=0.003)$. However, G2 and G5 did not differ in tiller count variation $(\mathrm{p}=0.057)$.

\section{Discussion}

In this study, we showed that micropropagation was effective and efficient for a non-model grass species with implications for other ecologically important plants. We found that we were able to propagate, root, and acclimate 360 total plants over slightly less than six months. Propagation rates for the different genotypes of $A$. gerardii were higher than traditional propagation techniques in this species (e.g., rhizome propagation in the greenhouse). Hartnett (1989) found multiplication rates for $A$. gerardii in the greenhouse were between $0.1 \times$ and $0.4 \times$ plants per week at low density. At higher density, multiplication rates were lower [52]. Commercial cultivars grown over several years yielded $0.2 \times$ plants per week [53]. We observed greenhouse multiplication rates of $0.04 \times$, $0.1 \times$, and $0.05 \times$ for G2, G5, and G11, respectively, when pots were kept at $25 \%$ volumetric water content over 15 months [54]. Another study examining A. gerardii and $A$. hallii hybrids took over three years to propagate sufficient clones [55]. In other cases, studies using rhizome propagation of $A$. gerardii did not specify rates or duration [56] or used genetically recombined seed [44]. Overall, the rhizome propagation rates are between $<1$ and $11 \%$ of the rates we observed with micropropagation. This difference is substantial, but the micropropagation advantage could vary among other non-model plant species.

Because the three $A$. gerardii genotypes we examined co-occur at the plot level, we would expect them to have different ecological niches and phenotypes [42] [46] potentially leading to cascading community effects. We found that mean trait values differed among genotypes even when plants were very young. Adult G2 tended to have fewer, large tillers compared to G11, which could represent early onset of different intraspecific growth strategies and resource allocation. Differences in variance among genotypes were also common and might reflect genotype differences in plasticity, a genetic characteristic that is likely independent of propagation technique [46] [57] [58] [59]. These results demonstrate the importance of intraspecific diversity even within a single population. Phenotypic differences were evident despite growing in a very controlled tissue culture environment. Our findings also suggest the importance of controlling for genotype in statistical models even when plants appear similar.

Many genetic diversity studies focus on a few key species, such as Oenothera biennis [4] [60] [61] [62] [63] or Solidago altissima [1] [5] [64], indicating that once a system is established, subsequent studies might become more practical. However, as climate changes worsen, understanding the effects of genetic diversity on less studied species will become more critical. Some ecologically dominant species (such as $A$. gerardii, Bouteloua gracilis-blue grama grass, Spartina 
alterniflora-smooth cordgrass, Populus tremuloides-trembling aspen, and Taxodium distichum baldcypress) tend to reproduce asexually, suggesting that they could be particularly amenable to micropropagation [7] [65] [66]. Micropropagation might also allow for more thorough investigation of intraspecific diversity beyond ecotype due to its rapid turn-around and potential to produce large numbers of individuals. Future study could then incorporate other levels of intraspecific diversity, such as phylogenetic relatedness among genotypes to explain variation in ecosystem function [47].

Most genetic diversity studies use seeds from different sources to represent different genotypes [6] [19] [67]-[72]. Seeds are readily attainable and minimize starting time for experiments. Yet, while model species such as Arabidopsis thaliana can self-pollinate and reach maturity quickly, an estimated 39\% of angiosperms are self-incompatible [73] and many have long life spans, making inbred lines impossible to generate. Seeds also can be limited to commercial cultivars or vulnerable to the mismatch between the scale of genetic diversity compared to the environmental or spatial scale of the experiment [74]. In self-incompatible species, propagation techniques might be the only option for working with genotypes or ecotypes of interest. Greenhouse propagation can take months to several years [20] [75]-[81], even with added growth hormones [75] [80]. Given the issues with genetic diversity studies using traditional methods and the evidence we present above, we suggest that micropropagation is a useful alternative. Although few ecological studies exist using micropropagation, several have been successful when laboratory resources were available [7] [65].

Although micropropagation is a highly effective technique, there are a number of limitations worth acknowledging. First, plants might develop somaclonal variation. In crop development, undifferentiated callus tissue can develop novel alleles overtime [82]. Rather than use callus tissue, we took advantage of natural budding from stem and rhizome meristem in $A$. gerardii. Plants experienced rapid rates of production even with the low dose of growth hormone $\mathrm{N}^{6}$-Benzyladenine (an artificial cytokinin). Because all genotypes began culture at the same time, we expect the amount of novel somaclonal variation to be approximately equal in each genotype, and therefore, not a confounding variable. Assuming constant mutation rates within a species, this would also be a problem for traditionally propagated plants. Furthermore, Avolio et al. [41] found genetic variation among clones that were physically connected by rhizome in the field. Thus, some variation could be unavoidable among clones in A. gerardii and potentially other species.

Micropropagation is necessarily sterile, yet many plants rely on mycorrhizae or endosymbiotic bacteria for normal function. The establishment of sterile lines in tissue culture eliminates most if not all of these important microorganisms, including within $A$. gerardii, which relies strongly on mycorrhizal fungi for phosphorusacquisition [83] [84] [85]. Although plants in micropropagation are supplemented by nutrients, transitioning back to a symbiotic relationship after 
growing in sterile tissue culture might be stressful (although we observed $<1 \%$ mortality leaving tissue culture). While some stress for the plant is unavoidable, we suggest lack of microorganisms can be remedied by inoculating media with native soil following the transfer of plants from tissue culture to greenhouse or laboratory conditions. In contrast, sterility offers the opportunity to study plant performance under different microbial conditions that are not available when using field-collected individuals for propagation.

Our understanding of intraspecific diversity is still limited in non-model and ecologically important species despite the pressing effects of globalchange. Future manipulative experiments must be able to increase sample sizes and account for variation among individuals to increase statistical power and be more confident in their conclusions. We propose that micropropagation will be most useful in clonally reproducing, self-incompatible plant species where 1) greenhouse propagation is time-limiting and 2) large numbers of plants are needed. Because we were able to perform a large portion of our micropropagation collaboratively, costs were greatly reduced overall, and made tissue culture a rapid, cost-effective method for our study. Many ecological labs might be able to collaborate with crop science or horticulture labs within academic institutions. Although long-term experiments using traditional propagation are feasible, shorter experiments using micropropagation are likely more appropriate for student projects or for short-term grants. For example, this technique allowed us to complete an entire study in approximately eight months instead of years. In the future, researchers will need to evaluate the costs and benefits of different propagation methods in their species of choice while ensuring techniques are as ecologically representative as possible.

\section{Acknowledgements}

Support was provided to M.D.S. by the United States Department of Energy, Office of Environment and Science (grant number DE-FG02-04ER63892). We would like to thank S. King for expertise and guidance on tissue culture protocols. We thank C. Walters, L. Hill, J. Crane, and R. Bonnart for their expertise and assistance in the United States Department of Agriculture - National Center for Genomic Resources Preservation facility.

\section{Conflicts of Interest}

The authors declare no conflicts of interest regarding the publication of this paper.

\section{References}

[1] Crutsinger, G.M., Collins, M.D., Fordyce, J.A., Gompert, Z., Nice, C.C. and Sanders, N.J. (2006) Plant Genotypic Diversity Predicts Community Structure and Governs an Ecosystem Process. Science, 313, 966-968.

https://doi.org/10.1126/science.1128326 
[2] Whitlock, R. (2014) Relationships between Adaptive and Neutral Genetic Diversity and Ecological Structure and Functioning: A Meta-Analysis. Journal of Ecology, 102, 857-872. https://doi.org/10.1111/1365-2745.12240

[3] Hughes, A.R., Inouye, B.D., Johnson, M.T.J., Underwood, N. and Vellend, M. (2008) Ecological Consequences of Genetic Diversity. Ecology Letters, 11, 609-623. https://doi.org/10.1111/j.1461-0248.2008.01179.x

[4] Cook-Patton, S.C., McArt, S.H., Parachnowitsch, A.L., Thaler, J.S. and Agrawal, A.A. (2011) A Direct Comparison of the Consequences of Plant Genotypic and Species Diversity on Communities and Ecosystem Function. Ecology, 92, 915-923. http://www.ncbi.nlm.nih.gov/pubmed/21661554 https://doi.org/10.1890/10-0999.1

[5] Crutsinger, G.M., Sanders, N.J. and Classen, A.T. (2009) Comparing Intra- and Inter-Specific Effects on Litter Decomposition in an Old-Field Ecosystem. Basic and Applied Ecology, 10, 535-543. https://doi.org/10.1016/j.baae.2008.10.011

[6] Crawford, K.M. and Whitney, K.D. (2010) Population Genetic Diversity Influences Colonization Success. Molecular Ecology, 19, 1253-1263.

https://doi.org/10.1111/j.1365-294X.2010.04550.x

[7] Avolio, M.L., Chang, C.C., Weis, J.J. and Smith, M.D. (2015) The Effect of Genotype Richness and Genomic Dissimilarity of Andropogon Gerardii on Invasion Resistance and Productivity. Plant Ecology \& Diversity, Taylor \& Francis, 8, 61-71. https://doi.org/10.1080/17550874.2013.866990

[8] Whitlock, R., Grime, J.P., Booth, R. and Burke, T. (2007) The Role of Genotypic Diversity in Determining Grassland Community Structure under Constant Environmental Conditions. Journal of Ecology, 95, 895-907. https://doi.org/10.1111/j.1365-2745.2007.01275.x

[9] Cassey, P., Cassey, P., Blackburn, T. and Blackburn, T. (2006) Reproducibility and Repeatability in Ecology. BioScience, 56, 958-959. https://doi.org/10.1641/0006-3568(2006)56[958:RARIE]2.0.CO;2

[10] Reichman, O.J., Jones, M.B. and Schildhauer, M.P. (2011) Challenges and Opportunities of Open Data in Ecology. Science, 331, 703-705.

https://doi.org/10.1126/science.1197962

[11] Lemoine, N.P., Hoffman, A., Felton, A.J., Baur, L., Chaves, F., Gray, J., Yu, Q. and Smith, M.D. (2016) Underappreciated Problems of Low Replication in Ecological Field Studies. Ecology, 97, 2554-2561. https://doi.org/10.1002/ecy.1506

[12] Barah, P. and Bones, A.M. (2014) Multidimensional Approaches for Studying Plant Defence against Insects: From Ecology to Omics and Synthetic Biology. Journal of Experimental Botany, 66, 479-493. https://doi.org/10.1093/jxb/eru489

[13] Dávalos, A., Nuzzo, V. and Blossey, B. (2014) Demographic Responses of Rare Forest Plants to Multiple Stressors: The Role of Deer, Invasive Species and Nutrients. Journal of Ecology, 102, 1222-1233. https://doi.org/10.1111/1365-2745.12279

[14] Gehring, C., Flores-Rentería, D., Sthultz, C.M., Leonard, T.M., Flores-Rentería, L., Whipple, A.V. and Whitham, T.G. (2014) Plant Genetics and Interspecific Competitive Interactions Determine Ectomycorrhizal Fungal Community Responses to Climate Change. Molecular Ecology, 23, 1379-1391.

https://doi.org/10.1111/mec.12503

[15] Atkinson, N.J., Jain, R. and Urwin, P.E. (2015) The Response of Plants to Simultaneous Biotic and Abiotic Stress. In: Mahalingam, R., Ed., Combined Stresses in Plants, 181-201. 
[16] Crutsinger, G.M., Strauss, S.Y. and Rudgers, J.E.R. (2010) Genetic Variation within a Dominant Shrub Species Determines Plant Species Colonization in a Coastal Dune Ecosystem. Ecology, 91, 1237-1243. https://doi.org/10.1890/09-0613.1

[17] Busby, P.E., Newcombe, G., Dirzo, R. and Whitham, T.G. (2014) Differentiating Genetic and Environmental Drivers of Plant-Pathogen Community Interactions. Journal of Ecology, 102, 1300-1309. https://doi.org/10.1111/1365-2745.12270

[18] Gustafson, D.J., Major, C., Jones, D., Synovec, J., Baer, S.G. and Gibson, D.J. (2014) Genetic Sorting of Subordinate Species in Grassland Modulated by Intraspecific Variation in Dominant Species. PLoS ONE, 9, e91511. https://doi.org/10.1371/journal.pone.0091511

[19] Abdala-Roberts, L., Berny-Mier y Terán, J.C., Moreira, X., Durán-Yáñez, A. and Tut-Pech, F. (2015) Effects of Pepper (Capsicum chinense) Genotypic Diversity on Insect Herbivores. Agricultural and Forest Entomology, 17, 433-438. https://doi.org/10.1111/afe.12125

[20] Booth, R.E. and Grime, J.P. (2003) Effects of Genetic Impoverishment on Plant Community Diversity. Journal of Ecology, 91, 721-730. https://doi.org/10.1046/j.1365-2745.2003.00804.x

[21] Tomimatsu, H., Nakano, K., Yamamoto, N. and Suyama, Y. (2014) Effects of Genotypic Diversity of Phragmites australis on Primary Productivity and Water Quality in an Experimental Wetland. Oecologia, 175, 163-172. https://doi.org/10.1007/s00442-014-2896-8

[22] Thorpe, T.A. (2007) History of Plant Tissue Culture. Molecular Biotechnology, 37, 169-180. https://doi.org/10.1007/s12033-007-0031-3

[23] Gupta, P.K. and Timmis, R. (2005) Mass Propagation of Conifer Trees in Liquid Cultures-Progress towards Commercialization. Plant Cell, Tissue and Organ Culture, 81, 339-346. https://doi.org/10.1007/s11240-004-6654-1

[24] Sudhersan, C., AboEl-Nil, M. and Hussain, J. (2003) Tissue Culture Technology for the Conservation and Propagation of Certain Native Plants. Journal of Arid Environments, 54, 133-147. https://doi.org/10.1006/jare.2001.0884

[25] Cook, B.I., Ault, T.R. and Smerdon, J.E. (2015) Unprecedented 21st Century Drought Risk in the American Southwest and Central Plains. Science Advances, 1, e1400082. https://doi.org/10.1126/sciadv.1400082

[26] Smith, M.D. and Knapp, A.K. (2003) Dominant Species Maintain Ecosystem Function with Non-Random Species Loss. Ecology Letters, 6, 509-517. https://doi.org/10.1046/j.1461-0248.2003.00454.x

[27] Johnson, R.G. and Anderson, R.C. (1986) The Seed Bank of a Tallgrass Prairie in Illinois. The American Midland Naturalist, 115, 123-130.

http://www.jstor.org/pss/2425842

https://doi.org/10.2307/2425842

[28] Abrams, M.D. (1988) Effects of Burning Regime on Buried Seed Banks and Canopy Coverage in a Kansas Tallgrass Prairie. The Southwestern Naturalist, 33, 65-70. https://doi.org/10.2307/3672089

[29] Hendrickson, J.R. and Briske, D.D. (1997) Axillary Bud Banks of Two Semiarid Perennial Grasses: Occurrence, Longevity, and Contribution to Population Persistence. Oecologia, 110, 584-591. https://doi.org/10.1007/s004420050199

[30] McDonough, W.T. (1979) Quaking Aspen Seed Germination and Early Seedling Growth. USDA Forest Service Research.

[31] Norrmann, G.A. and Keeler, K.H. (2003) Cytotypes of Andropogon gerardii Vit- 
man (Poaceae): Fertility and Reproduction of Aneuploids. Botanical Journal of the Linnean Society, 141, 95-103. https://doi.org/10.1046/j.1095-8339.2003.00116.x

[32] Lee, C.E. (2002) Evolutionary Genetics of Invasive Species. Trends in Ecology \& Evolution, 17, 386-391. https://doi.org/10.1016/S0169-5347(02)02554-5

[33] Keeler, K.H. (2004) Impact of Intraspecific Polyploidy in Andropogon gerardii (Poaceae) Populations. The American Midland Naturalist, 152, 63-74. https://doi.org/10.1674/0003-0031(2004)152[0063:IOIPIA]2.0.CO;2

[34] Norrmann, G.A. (2009) Natural Hybridization in the Andropogon lateralis Complex (Andropogoneae, Poaceae) and Its Impact on Taxonomic Literature. Botanical Journal of the Linnean Society, 159, 136-154. https://doi.org/10.1111/j.1095-8339.2008.00904.x

[35] Chen, C.H., Stenberg, N.E. and Ross, J.G. (1977) Clonal Propagation of Big Bluestem by Tissue Culture. Crop Science, 17, 847-850. https://doi.org/10.2135/cropsci1977.0011183X001700060007x

[36] USDA (2015) The PLANTS Database. United States Department of Agriculture, Natural Resources Conservation Service, National Plant Data Team, Greensboro, NC, USA. http://plants.usda.gov

[37] Koerner, S.E., Burkepile, D.E., Fynn, R.W.S., Burns, C.E., Eby, S., Govender, N., Hagenah, N., Matchett, K.J., Thompson, D.I., Wilcox, K.R., Collins, S.L., Kirkman, K.P., Knapp, A.K. and Smith, M.D. (2014) Plant Community Response to Loss of Large Herbivores Differs between North American and South African Savanna Grasslands. Ecology, 95, 808-816. https://doi.org/10.1890/13-1828.1

[38] Pedroso, G.M., Hutmacher, R.B., Putnam, D., Six, J., van Kessel, C. and Linquist, B.A. (2014) Biomass Yield and Nitrogen Use of Potential C4 and C3 Dedicated Energy Crops in a Mediterranean Climate. Field Crops Research, 161, 149-157.

[39] Zhang, K., Johnson, L., Vara Prasad, P.V., Pei, Z. and Wang, D. (2015) Big Bluestem as a Bioenergy Crop: A Review. Renewable and Sustainable Energy Reviews, 52, 740-756. https://doi.org/10.1016/j.rser.2015.07.144

[40] Travers, S.E., Tang, Z., Caragea, D., Garrett, K.A., Hulbert, S.H., Leach, J.E., Bai, J., Saleh, A., Knapp, A.K., Fay, P.A., Nippert, J., Schnable, P.S. and Smith, M.D. (2010) Variation in Gene Expression of Andropogon gerardii in Response to Altered Environmental Conditions Associated with Climate Change. Journal of Ecology, 98, 374-383. https://doi.org/10.1111/j.1365-2745.2009.01618.x

[41] Avolio, M.L., Chang, C.C. and Smith, M.D. (2011) Assessing Fine-Scale Genotypic Structure of a Dominant Species in Native Grasslands. The American Midland Naturalist, 165, 211-224. https://doi.org/10.1674/0003-0031-165.2.211

[42] Avolio, M.L., Beaulieu, J.M., Lo, E.Y.Y. and Smith, M.D. (2012) Measuring Genetic Diversity in Ecological Studies. Plant Ecology, 213, 1105-1115.

https://doi.org/10.1007/s11258-012-0069-6

[43] Chang, C.C. and Smith, M.D. (2014) Direct and Indirect Relationships between Genetic Diversity of a Dominant Grass, Community Diversity and above-Ground Productivity in Tallgrass Prairie. Journal of Vegetation Science, 25, 470-480. https://doi.org/10.1111/jvs.12108

[44] Gray, M.M., St Amand, P., Bello, N.M., Galliart, M.B., Knapp, M., Garrett, K.A., Morgan, T.J., Baer, S.G., Maricle, B.R., Akhunov, E.D. and Johnson, L.C. (2014) Ecotypes of an Ecologically Dominant Prairie Grass (Andropogon gerardii) Exhibit Genetic Divergence across the U.S. Midwest Grasslands' Environmental Gradient. Molecular Ecology, 23, 6011-6028. https://doi.org/10.1111/mec.12993 
[45] Smith, M.D., Hoffman, A.M. and Avolio, M.L. (2016) Gene Expression Patterns of Two Dominant Tallgrass Prairie Species Differ in Response to Warming and Altered Precipitation. Scientific Reports, 6, Article No. 25522.

[46] Avolio, M.L. and Smith, M.D. (2013) Mechanisms of Selection: Phenotypic Differences among Genotypes Explain Patterns of Selection in a Dominant Species. Ecology, 94, 953-965. https://doi.org/10.1890/12-1119.1

[47] Avolio, M.L., Beaulieu, J.M. and Smith, M.D. (2013) Genetic Diversity of a Dominant C4 Grass Is Altered with Increased Precipitation Variability. Oecologia, 171, 571-581. https://doi.org/10.1007/s00442-012-2427-4

[48] NOAA (2012) United States Drought Monitor. National Drought Mitigation Center (NDMC), the U.S. Department of Agriculture (USDA), and the National Oceanic and Atmospheric Administration (NOAA).

[49] Knapp, A.K., Carroll, C.J.W., Denton, E.M., La Pierre, K.J., Collins, S.L. and Smith, M.D. (2015) Differential Sensitivity to Regional-Scale Drought in Six Central US Grasslands. Oecologia, 177, 949-957. https://doi.org/10.1007/s00442-015-3233-6

[50] Murashige, T. and Skoog, F. (1962) A Revised Medium for Rapid Growth and Bio Assays with Tobacco Tissue Cultures. Physiologia Plantarum, 15, 473-497. https://doi.org/10.1111/j.1399-3054.1962.tb08052.x

[51] R Core Team (2018) R: A Language and Environment for Statistical Computing, Version 3.5.0. https://www.r-project.org

[52] Hartnett, D.C. (1989) Density- and Growth Stage-Dependent Responses to Defoliation in Two Rhizomatous Grasses. Oecologia, 80, 414-420. https://doi.org/10.1007/BF00379045

[53] Tallarico, J.P., Voigt, T.B. and Robertson, K.R. (2004) “Prairie Chief” Big Bluestem. HortScience, 39, 639-641.

[54] Hoffman, A.M. and Smith, M.D. Nonlinear Plasticity Improves Understanding of Intraspecific Diversity in an Ecological Model Species. In Preperation.

[55] Peters, L.V and Newell, L.C. (1961) Hybridization Between Divergent Types of Big Bluestem, Andropogon gerardi Vitman, and Sand Bluestem, Andropogon hallii Hack. Crop Science, 1, 359-363. https://doi.org/10.2135/cropsci1961.0011183X000100050019x

[56] Keeler, K.H., Williams, C.F. and Vescio, L.S. (2002) Clone Size of Andropogon gerardii Vitman (Big Bluestem) at Konza Prairie, Kansas. The American Midland Naturalist, 147, 295-304. https://doi.org/10.1674/0003-0031(2002)147[0295:CSOAGV]2.0.CO;2

[57] Nicotra, A.B. and Davidson, A. (2010) Adaptive Phenotypic Plasticity and Plant Water Use. Functional Plant Biology, 37, 117-127. https://doi.org/10.1071/FP09139

[58] Molina-Montenegro, M.A. and Naya, D.E. (2012) Latitudinal Patterns in Phenotypic Plasticity and Fitness-Related Traits: Assessing the Climatic Variability Hypothesis $(\mathrm{CVH})$ with an Invasive Plant Species. PLoS ONE, 7, e47620.

[59] Forsman, A. (2015) Rethinking Phenotypic Plasticity and Its Consequences for Individuals, Populations and Species. Heredity, 115, 276-284.

[60] Parachnowitsch, A.L., Cook-Patton, S.C. and McArt, S.H. (2014) Neighbours Matter: Natural Selection on Plant Size Depends on the Identity and Diversity of the Surrounding Community. Evolutionary Ecology, 28, 1139-1153. https://doi.org/10.1007/s10682-014-9727-6

[61] Johnson, M.T.J. (2008) Bottom-Up Effects of Plant Genotype on Aphids, Ants, and Predators. Ecology, 89, 145-154. https://doi.org/10.1890/07-0395.1 
[62] Johnson, M.T.J., Lajeunesse, M.J. and Agrawal, A. (2006) Additive and Interactive Effects of Plant Genotypic Diversity on Arthropod Communities and Plant Fitness. Ecology Letters, 9, 24-34.

[63] McArt, S.H. and Thaler, J.S. (2013) Plant Genotypic Diversity Reduces the Rate of Consumer Resource Utilization. Proceedings of the Royal Society B: Biological Sciences, 280, Article ID: 20130639. https://doi.org/10.1098/rspb.2013.0639

[64] Crutsinger, G.M., Reynolds, W.N., Classen, A.T. and Sanders, N.J. (2008) Disparate Effects of Plant Genotypic Diversity on Foliage and Litter Arthropod Communities. Oecologia, 158, 65-75. https://doi.org/10.1007/s00442-008-1130-y

[65] Madritch, M., Donaldson, J.R. and Lindroth, R.L. (2006) Genetic Identity of PopuIus tremuloides Litter Influences Decomposition and Nutrient Release in a Mixed Forest Stand. Ecosystems, 9, 528-537. https://doi.org/10.1007/s10021-006-0008-2

[66] Chang, C.C. and Smith, M.D. (2014) Resource Availability Modulates Above- and Below-Ground Competitive Interactions between Genotypes of a Dominant $\mathrm{C}_{4}$ Grass. Functional Ecology, 28, 1041-1051.

[67] Bischoff, A., Steinger, T. and Mller-Schärer, H. (2010) The Importance of Plant Provenance and Genotypic Diversity of Seed Material Used for Ecological Restoration. Restoration Ecology, 18, 338-348. https://doi.org/10.1111/j.1526-100X.2008.00454.x

[68] Rowntree, J.K., Cameron, D.D. and Preziosi, R.F. (2011) Genetic Variation Changes the Interactions between the Parasitic Plant-Ecosystem Engineer Rhinanthus and Its Hosts. Philosophical Transactions of the Royal Society of London. Series B, Biological Sciences, 366, 1380-1388. https://doi.org/10.1098/rstb.2010.0320

[69] Gibson, D.J., Baer, S.G., Klopf, R.P., Reed, L.K., Wodika, B.R. and Willand, J.E. (2013) Limited Effects of Dominant Species Population Source on Community Composition during Community Assembly. Journal of Vegetation Science, 24, 429-440. https://doi.org/10.1111/j.1654-1103.2012.01475.x

[70] Baer, S.G., Gibson, D.J., Gustafson, D.J., Benscoter, A.M., Reed, L.K., Campbell, R.E., Klopf, R.P., Willand, J.E. and Wodika, B.R. (2014) No Effect of Seed Source on Multiple Aspects of Ecosystem Functioning during Ecological Restoration: Cultivars Compared to Local Ecotypes of Dominant Grasses. Evolutionary Applications, 7, 323-335.

[71] terHorst, C.P. and Lau, J. (2014) Genetic Variation in Invasive Species Response to Direct and Indirect Species Interactions. Biological Invasions, 17, 651-659. https://doi.org/10.1007/s10530-014-0756-4

[72] Harter, D.E.V., Nagy, L., Backhaus, S., Beierkuhnlein, C., Fussi, B., Huber, G., Jentsch, A., Konnert, M., Thiel, D. and Kreyling, J. (2015) A Comparison of Genetic Diversity and Phenotypic Plasticity among European Beech (Fagus sylvatica L.) Populations from Bulgaria and Germany under Drought and Temperature Manipulation. International Journal of Plant Sciences, 176, 232-244. https://doi.org/10.1086/679349

[73] Igic, B., Lande, R. and Kohn, J.R. (2008) Loss of Self-Incompatibility and Its Evolutionary Consequences. International Journal of Plant Sciences, 169, 93-104. https://doi.org/10.1086/523362

[74] Tack, A.J.M., Johnson, M.T.J. and Roslin, T. (2012) Sizing up Community Genetics: It's a Matter of Scale. Oikos, 121, 481-488. https://doi.org/10.1111/j.1600-0706.2011.19926.x

[75] Dhillon, R.S., Hooda, M.S., Pundeer, J.S., Ahlawat, K.S. and Chopra, I. (2011) Effects of Auxins and Thiamine on the Efficacy of Techniques of Clonal Propagation 
in Jatropha curcas L. Biomass and Bioenergy, 35, 1502-1510. https://doi.org/10.1016/j.biombioe.2010.12.017

[76] Koch, C. and Kollmann, J. (2012) Clonal Re-Introduction of Endangered Plant Species: The Case of German False Tamarisk in Pre-Alpine Rivers. Environmental Management, 50, 217-225. https://doi.org/10.1007/s00267-012-9880-Z

[77] Vieira, D.L.M., Coutinho, A.G. and Da Rocha, G.P.E. (2013) Resprouting Ability of Dry Forest Tree Species after Disturbance Does Not Relate to Propagation Possibility by Stem and Root Cuttings. Restoration Ecology, 21, 305-311. https://doi.org/10.1111/j.1526-100X.2012.00935.x

[78] D’Hertefeldt, T., Eneström, J.M. and Pettersson, L.B. (2014) Geographic and Habitat Origin Influence Biomass Production and Storage Translocation in the Clonal Plant Aegopodium podagraria. PLoS ONE, 9, e85407.

[79] Engelhardt, K., Lloyd, M.W. and Neel, M.C. (2014) Effects of Genetic Diversity on Conservation and Restoration Potential at Individual, Population, and Regional Scales. Biological Conservation, 179, 6-16.

https://doi.org/10.1016/j.biocon.2014.08.011

[80] Hughes, M. and Smith, J. (2014) Vegetative Propagation of Putatively Laurel Wilt-Resistant Redbay (Persea borbonia). Native Plants Journal, 15, 42-50. http://npj.uwpress.org/content/15/1/42.short

[81] Roiloa, S.R., Sánchez-Rodríguez, P. and Retuerto, R. (2014) Heterogeneous Distribution of Soil Nutrients Increase Intra-Specific Competition in the Clonal Plant Glechoma hederacea. Plant Ecology, 215, 863-873. https://doi.org/10.1007/s11258-014-0338-7

[82] Larkin, P.J. and Scowcroft, W.R. (1981) Somaclonal Variation-A Novel Source of Variability from Cell Cultures for Plant Improvement. Theoretical and Applied Genetics, 60, 197-214. https://doi.org/10.1007/BF02342540

[83] Wilson, G.W.T. and Hartnett, D.C. (1997) Effects of Mycorrhizae on Plant Growth and Dynamics in Experimental Tallgrass Prairie Microcosms. American Journal of Botany, 84, 478-482. https://doi.org/10.2307/2446024

[84] Johnson, N.C., Rowland, D.L., Corkidi, L., Egerton-Warburton, L.M. and Allen, E.B. (2003) Nitrogen Enrichment Alters Mycorrhizal Allocation at Five Mesic to Semiarid Grasslands. Ecology, 84, 1895-1908. https://doi.org/10.1890/0012-9658(2003)084[1895:NEAMAA]2.0.CO;2

[85] Johnson, N. (2010) Resource Stoichiometry Elucidates the Structure and Function of Arbuscular Mycorrhizas across Scales. New Phytologist, 185, 631-647. http://onlinelibrary.wiley.com/doi/10.1111/j.1469-8137.2009.03110.x/full https://doi.org/10.1111/j.1469-8137.2009.03110.x 